\title{
Effect of Streptomycin and Gentamycin on in vitro Growth and Cultural Contaminants of Potato Cultivars
}

\author{
Tanuja Buckseth*, R.K. Singh, Ashwani K. Sharma, Sumita Sharma, \\ Vaishali Modgil and Aastha Saraswati
}

\author{
ICAR-Central Potato Research Institute, Shimla- 171001, (H.P.), India \\ *Corresponding author
}

\section{A B S T R A C T}

\begin{tabular}{|l|}
\hline Ke y w o r d s \\
Microplants, \\
Antibiotics, \\
Varieties, Potato. \\
\hline Article Info \\
\hline $\begin{array}{l}\text { Accepted: } \\
\text { 23 November } 2017 \\
\text { Available Online: } \\
10 \text { December } 2017\end{array}$ \\
\hline
\end{tabular}

Considering the cultural contamination problems, an experiment was conducted by using antibiotics (Streptomycin and Gentamycin) for different potato varieties (Kufri Jyoti, Kufri Sadabahar, Kufri Lauvkar and Kufri Sindhuri) at different concentrations to find out contamination free, vigorous in-vitro growth of the potato microplants in MS media. It was observed that lower concentration of Streptomycin $(0.1 \%$ and $0.2 \%)$ can be incorporated in the micropropagation medium of potato to minimize microbial contaminants as well as for improving the vigour of microplantlets, whereas all the concentrations of Gentamycin had negative effect on all the morphological characters studied which needs further investigation with lower concentration. However, all the cultural contamination was completely checked.

\section{Introduction}

Plant tissue culture, like many other technologies is a well-established technology which has gone through different stages of evolution; scientific curiosity, research tool, novel applications and mass exploitation. It is a technology which is being widely used for large scale plant multiplication. Apart from its use as a research tool, this technique also has a major industrial importance in the area of plant propagation, disease elimination, plant improvement and production of secondary metabolites. Small pieces of tissue (named explants) can be used to produce hundreds and thousands of plants in a continuous process. A single explant can be multiplied into several thousand plants in relatively short time period and space under controlled conditions, irrespective of the season and weather on a year round basis (Akin et al., 2009).

Although successful as a propagative technique, plant tissue culture is not without problems. One of the most important is culture contamination, especially where caused by bacteria. Bacterial contamination may appear in Stage II, the multiplication stage in Murashige's scheme for production, even with the most careful workers (Murashige, 1974). Bacterial contaminations are a serious problem in plant in vitro cultures, both in commercial plant 
micropropagation, by making difficult culture initiation, reducing efficiency of multiplication and rooting of shoots, as well as in research laboratories, where contamination can be the causal agent of false results in physiological experiments (Holland et al., 1994; Orlikowska et al., 2006; Orlikowska et al., 2010). Preventing or avoiding microbial contamination of plant tissue cultures is critical to successful micropropagation. Epiphytic and endophytic organisms can cause severe losses to micropropagated plants at each stage of growth (Cassells, 1991; Debergh and Vanderschaeghe, 1988; Leifert et al., 1991). Bacterial contaminants are often difficult to detect because they remain mostly within the plant tissue (Debergha and Vanderschaeghe, 1988; De Fossard and De Fossard, 1988; Viss et al., 1991). Contaminated plants may have no visible symptoms, reduced multiplication and rooting rates or may die (Leifert et al., 1989, 1992).

Introduction of microorganisms due to poor aseptic technique or improperly sterilized equipment can be corrected with improvements in training or equipment handling but eliminating internal contaminants is more problematic (Buckley et al., 1995). Though surface sterilization eliminates the exophytic microbes (George, 1993) but, endophytic bacterial contamination can only be eradicated by antibiotic therapy (Jung, 2003). Bacterial contaminations are a serious problem in plant in vitro cultures, both in commercial plant micropropagation, by making difficult culture initiation, reducing efficiency of multiplication and rooting of shoots, as well as in research laboratories, where contamination can be the causal agent of false results in physiological experiments. Therefore, an experiment was conducted with different concentrations of two antibiotics (streptomycin and gentamycin) for four varieties (Kufri Jyoti, Kufri Sadabahar, Kufri
Lauvkar and Kufri Sindhuri) to find out contamination free, vigorous in vitro growth of the microplant in MS media.

\section{Materials and Methods}

The research was conducted at Central Potato Research Institute Shimla. The study included four different varieties of potato viz., Kufri Jyoti, Kufri Sadabhar, Kufri Lauvkar and Kufri Sindhuri. The explants used in the study were double-node cuttings derived from the middle portion of microplantlets. The standard culture MS (Murashige and Skoog, 1962) medium was used for the experiment. The broad spectrum antibiotic in liquid commercial formulation of PAA (Phenylacetic acid) make was used. The liquid formulation of streptomycin 100x and gentamycin $10 \mathrm{mg} / \mathrm{ml}$ of PAA make were added aseptically at various concentrations (for streptomycin $0.1 \%, 0.2 \%, 0.3 \%, 0.4 \%$, $0.5 \%$ and for gentamycin $10 \mathrm{ppm}, 25 \mathrm{ppm}$, $50 \mathrm{ppm}, 75 \mathrm{ppm}, 100 \mathrm{ppm}$ ) in the sterilized MS medium culture tubes. Three single node pieces of explants were vertically inserted in MS culture medium per tubes at equilateral distance. The explants (three double nodes per test tube) were cultured on above said media along with control in which no antibiotics were added. The culture tubes were kept for 21days in culture room with 16 hours light (irradiance of $60 \mu \mathrm{mol} / \mathrm{m}^{2} / \mathrm{s}$ ) and 8 hours dark photoperiodism at $22 \pm 1^{\circ} \mathrm{C}$ temperature. After 21 days of incubation, different growth parameters viz. microplant height, no. of nodes, no of leaves and no of roots was recorded. In case of roots as there was secondary branching so only primary roots were counted.

The experiment was conducted in a three way factorial $(2 \times 4 \times 5)$ completely randomized design. Each treatment comprised four replicates, each replicate consist of four test tubes having three plantlets. The three-way 
analysis of variance was done using the software AGRES and means were separated according to the least significant differences at 0.05 level of probability and the graphs were prepared with the graph pad prism 5.0 software.

\section{Results and Discussion}

In Kufri Jyoti, the microplant height was more than control at $0.1 \%$ and $0.2 \%$ concentration of streptomycin. However, Streptomycin at $0.2 \%$ concentration, the no. of leaves and no. of nodes were at par with control. Streptomycin irrespective of concentrations significantly increases the root no. As compare to control (Fig. 1). Gentamycin at all concentrations had nonsignificant effect on all growth parameters in comparison to control (Fig. 2). However in recent years, it has been suggested that the antibiotic, Gentamicin used successfully in control of contamination in animal tissue cultures, might prove effective for the same purpose in plant tissue culture (J. F. and M. E. Knauss, 1979).

In Kufri Sadabhar at $0.1 \%$ concentration of streptomycin, the microplant height was $3.7 \mathrm{~cm}$ and at $0.3 \%$ concentration of streptomycin, the no. of leaves and no. of nodes were 3 . These results were found better as compared to other concentrations, however the results were at par with the control (Fig. $3)$. The microplant height $(7 \mathrm{~cm})$, no. of leaves (4) and nodes in Kufri Sadabhar (3) at 10ppm concentration of gentamycin was at par with control.

However, higher concentrations of gentamycin (50ppm, 75ppm and 100ppm) retarded the growth of all other parameters (Fig. 4). Zhang et al., in 1999 reported that at higher concentrations of antibiotic products so formed degrade the polyribosome that can inhibit protein synthesis and disrupt the membrane permeability.

In Kufri Lauvkar, the microplant height and no. of roots were significantly increased at $0.1 \%$ concentration of streptomycin. As the concentration of streptomycin was increased, there was a decrease in the microplant height as well as no. of roots (Fig. 5). No. of leaves and no. of nodes, were at par with control at $0.1 \%$ and $0.2 \%$ concentration of streptomycin (Fig. 5). Chen and Yeh in 2007 reported that high concentration of streptomycin $(400 \mathrm{mg} / \mathrm{l})$ eliminates contamination but causes browning in most explants.

Fig.1 Kufri Jyoti with different concentrations of Streptomycin \& Fig.2 with Gentamycin
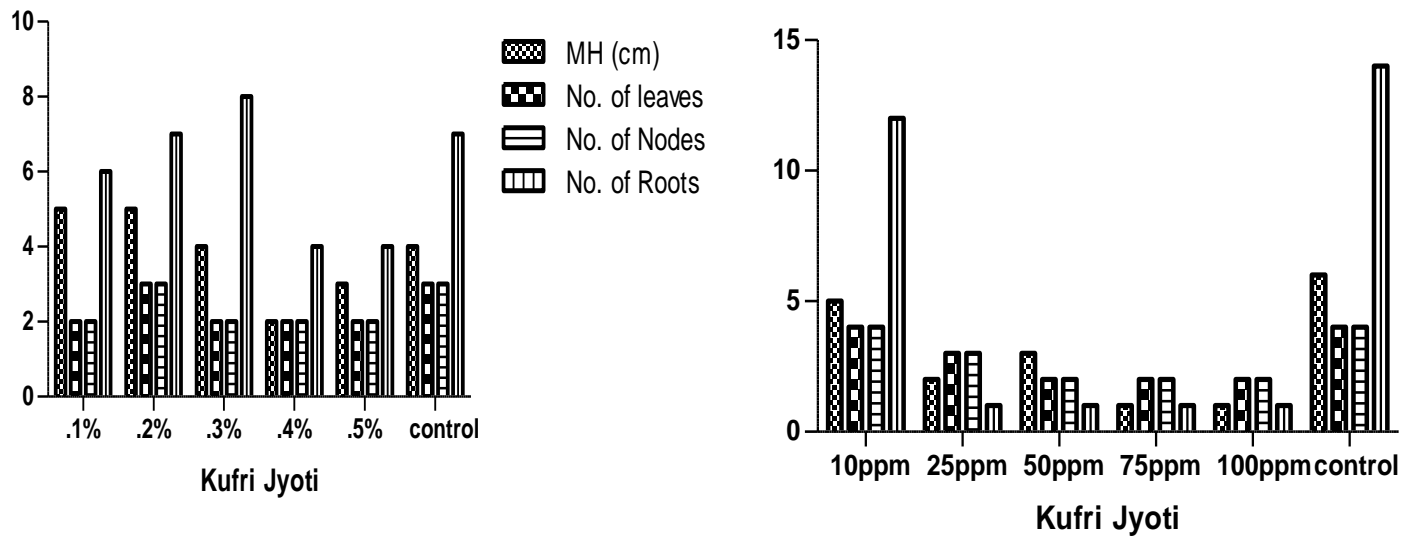
Fig.3 Kufri Sadabahar with different concentrations of Streptomycin \& Fig.4 with Gentamycin
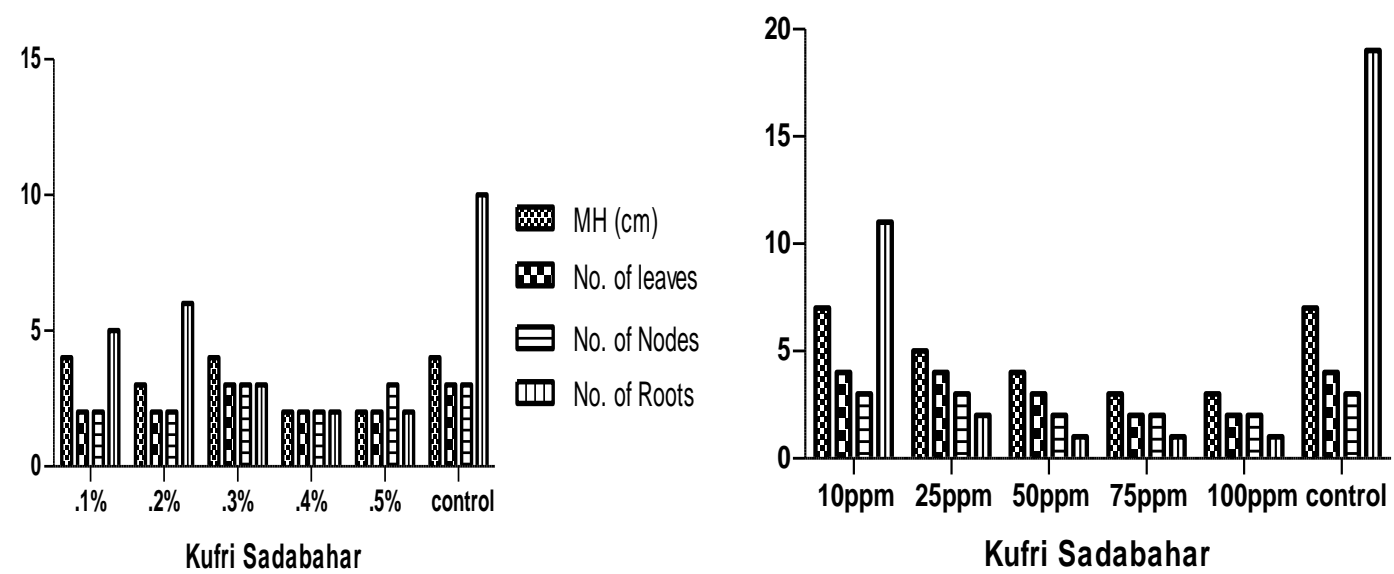

Fig.5 Kufri Lauvkar with different concentrations of Streptomycin \& Fig.6 with Gentamycin
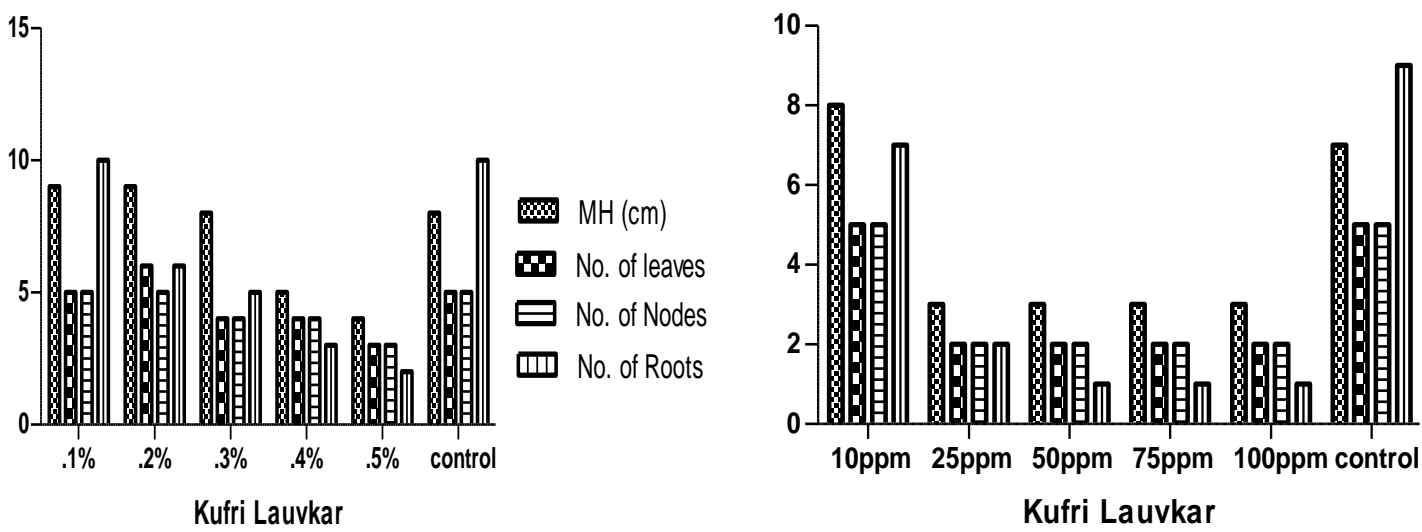

Fig.7 Kufri Sindhuri with different concentrations of Streptomycin \& Fig.8 with Gentamycin
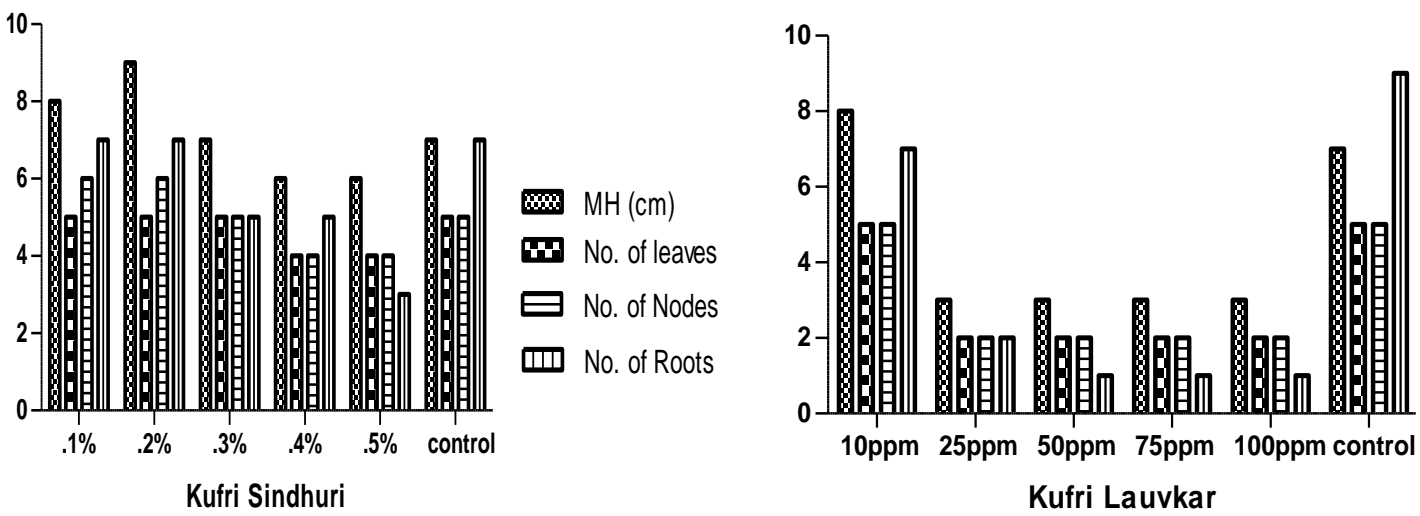
Gentamycin at 10ppm significantly increased microplant height, no. of leaves and nodes as compared to control and other concentrations of streptomycin. However, root no. was at par with control at 10ppm whereas, a decrease in the no. of roots was observed as the concentration of Gentamycin was increased (Fig. 6).

In Kufri Sindhuri, the microplant height was significantly increased at $0.1 \%$ concentration of streptomycin, however the effect of all other concentrations were at par with control whereas, for all other parameter the effect of all the concentration of Streptomycin was at par with each other and control (Fig. 7). At 25 ppm concentration of gentamycin, the microplant height was significantly more than control (Fig. 8) whereas, at10ppm the microplant height was at par with control. However, higher concentrations of gentamycin (50ppm, 75ppm and 100ppm) retarded the growth of all the parameters used in the study (Fig. 8). Negative effects of higher concentrations of both the antibiotics on almost all the morphological characters as observed in the present study may be due to toxic effects of these antibiotics and such effects have been reported in barley by Mathias and Mukasa, (1987). Plant growth promoting effect of these antibiotics might be responsible for the positive effect of these antibiotics upto certain concentrations on microplant vigour and growth (Venkataslam, et al., 2013). Genotype is all responsible to confer the micoplant sensitivity as well as tolerance limit to different antibiotics and other agents. Therefore, choice and optimization of these antibiotics concentration is prerequisite for different genotypes.

In general, lower concentration of Streptomycin can be incorporated in the micropropagation medium of potato to minimize microbial contaminants as well as for improving the vigour of microplantlets, whereas all the concentrations of Gentamycin had negative effect on all the morphological characters studied which needs further investigation with lower concentration.

\section{References}

Akin-Idowu, P.E., Ibitoye, D.O., Ademoyegun O.T. 2009. Tissue culture as a plant production technique for horticultural crops. Afr. J. Biotechnol. 8(16), 3782-3788.

Buckley, P.M., De Wilde, T.N. and Reed, B.M. 1995. Characterization and identification of bacteria isolated from micropropogated mint plants. In Vitro Cell. Dev. Biol.31, 58-64.

Cassells, A.C., 1991. Problems in tissue culture: Culture contamination. In: Micropropagation Technology and Application. (Eds. P.C. Debergh and R.H. Zimmerm). Kluwer Academic Publishers, Dordrecht, Netherlands. pp. 31-44.

Chen, W. L., and D.M. Yeh. 2007. Elimination of In vitro Contamination, Shoot Multiplication, and ex vitro rooting of Aglaonema. Hort Science 42(3), 629-632.

De Fossard, R.A., and De Fossard, H. 1988. Coping with microbial contaminants and other matters in a small commercial micropropagation laboratory. Acta Bort. 225, 167-176.

Debergh, P.C., and Vanderschaeghe, A. M. 1988. Some symptoms indicating the presence of bacterial contaminants in plant tissue culture. Acta Bort. 255, 7781.

George, E.F., 1993. Plant propagation by tissue culture. Exergetics Ltd., Edington, England: 574p.

Holland, M.A., and Polacco, J.C. 1994. PPFMs and other covert contaminants: is there more to plant physiology than just plant? Annu Rev Plant Physiol 
Plant Mol Biol.45, 197-209.

J. F., and M. E. Knauss. 1979. Contamination in Plant Tissue Cultures. Proc. Fla. State Hort. Soc. 92, 341-343.

Jung, V., 2003. The role of selected plant and microbial metabolites in the nutrient solution of closed growing systems in greenhouses. Swedish University of Agricultural Science. Dissertation, Agraria 418p.

Leifert, C., Camota, H., Wright, S.M. Waites, B., Cheyne, V.A. and Waites, W.M. 1991. Elimination of Laclobacillus planlarum, Corynebacterium spp. Staphylococcus saprophyticus and Pseudomonas paucimobilis from micropropagated Hemerocallis, Choisya and Delphinium cultures using antibiotics. J. Appl. Bact. 71, 307-330.

Leifert, C., Camotla, H. and Wailes. W.M. 1992. Effect of combinations of antibiotics on micropropagared Clematis. Delphinium, Hosta, Iris. And Photinia. Plant Cell Tissue Organ Cult. 29: 153-160.

Leifert. Co. Waites. W.M. and Nicholas, L.R. 1989. Bacterial contamination of micropropagated plant tissue cultures. $J$. Appl. Bact. 67, 353-361.

Mathias, R.J., and Mukasa, C. 1987. The effect of cefotaxime on the growth and regeneration of callus from varieties of barley (Hordeum vulgare L.). Plant Cell Rep 6, 454-57.
Murashige Toshio, and Folke Skoog. 1962. A Revised Medium for Rapid Growth and Bio Assays with Tobacco Tissue Cultures. Physiologia Plantarum. 15(3), 473-497.

Murashige, T., 1974. Plant propagation through tissue culture. Ann. Rev. Plant Physiol. 25, 135.

Orlikowska, T., and Zawadzka, M. 2006. In vitro/Bacteria in plant tissue culture. Biotechnologia. 4(75), 64-77 (in Polish with English abstract).

Orlikowska, T., Sobiczewski, P., Zawadzka, M., Zenkteler and E., Kontrola. (2010).The control and eradication of bacterial infections and contaminations in plant tissue culture. Biotechnologia. 2(89): 57-71 (in Polish with English abstract).

Venkatasalam, E.P., K.K. Pandey, B.P. Singh, Vandana Thakur, Shilpa Sharma, Richa Sood and Ashwani, K. Sharma.(2013). Efficacy of antimicrobial agents on in vitro micropropagation potential of potato. Potato J. 40 (1), 45-54.

Viss, P.R., Brooks, E.M. and Qriver, J.A. 1991. A simplified method for the control of bacterial contamination in woody plant tissue culture. In Vitro Cel.Dev. Biol. 27, 42-44.

Zhang, Q., Wiskich, J.T. and Woole, K.I. 1999. Respiratory activities in chlorophenicol- treated tobacco cells. Physiol Plantarum 105, 224-32.

\section{How to cite this article:}

Tanuja Buckseth, R.K. Singh, Ashwani K. Sharma, Sumita Sharma, Vaishali Modgil and Aastha Saraswati. 2017. Effect of Streptomycin and Gentamycin on in vitro Growth and Cultural Contaminants of Potato Cultivars. Int.J.Curr.Microbiol.App.Sci. 6(12): 4038-4043. doi: https://doi.org/10.20546/ijcmas.2017.612.464 